\title{
Front Matter: Volume 9223
}

, "Front Matter: Volume 9223," Proc. SPIE 9223, Remote Sensing System Engineering V, 922301 (3 October 2014); doi: 10.1117/12.2086915

SPIE Event: SPIE Optical Engineering + Applications, 2014, San Diego, California, SPIE. United States 


\title{
PROCEEDINGS OF SPIE
}

\section{Remote Sensing System Engineering $V$}

\author{
Philip E. Ardanuy \\ Jeffery J. Puschell \\ Editors
}

18 August 2014
San Diego, California, United States

Sponsored and Published by

SPIE 
The papers included in this volume were part of the technical conference cited on the cover and title page. Papers were selected and subject to review by the editors and conference program committee. Some conference presentations may not be available for publication. The papers published in these proceedings reflect the work and thoughts of the authors and are published herein as submitted. The publisher is not responsible for the validity of the information or for any outcomes resulting from reliance thereon.

Please use the following format to cite material from this book:

Author(s), "Title of Paper," in Remote Sensing System Engineering V, edited by Philip E. Ardanuy, Jeffery J. Puschell, Proceedings of SPIE Vol. 9223 (SPIE, Bellingham, WA, 2014) Article CID Number.

ISSN: 0277-786X

ISBN: 9781628412505

Published by

SPIE

P.O. Box 10, Bellingham, Washington 98227-0010 USA

Telephone +1 3606763290 (Pacific Time) · Fax +1 3606471445

SPIE.org

Copyright $@ 2014$, Society of Photo-Optical Instrumentation Engineers.

Copying of material in this book for internal or personal use, or for the internal or personal use of specific clients, beyond the fair use provisions granted by the U.S. Copyright Law is authorized by SPIE subject to payment of copying fees. The Transactional Reporting Service base fee for this volume is $\$ 18.00$ per article (or portion thereof), which should be paid directly to the Copyright Clearance Center (CCC), 222 Rosewood Drive, Danvers, MA 01923. Payment may also be made electronically through $\mathrm{CCC}$ Online at copyright.com. Other copying for republication, resale, advertising or promotion, or any form of systematic or multiple reproduction of any material in this book is prohibited except with permission in writing from the publisher. The CCC fee code is 0277-786X/14/\$18.00.

Printed in the United States of America.

Publication of record for individual papers is online in the SPIE Digital Library.

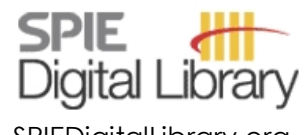

SPIEDigitalLibrary.org

Paper Numbering: Proceedings of SPIE follow an e-First publication model, with papers published first online and then in print and on CD-ROM. Papers are published as they are submitted and meet publication criteria. A unique, consistent, permanent citation identifier (CID) number is assigned to each article at the time of the first publication. Utilization of CIDs allows articles to be fully citable as soon as they are published online, and connects the same identifier to all online, print, and electronic versions of the publication. SPIE uses a six-digit CID article numbering system in which:

- The first four digits correspond to the SPIE volume number.

- The last two digits indicate publication order within the volume using a Base 36 numbering

system employing both numerals and letters. These two-number sets start with 00, 01, 02, 03, 04,

$05,06,07,08,09,0 A, 0 B \ldots$. OZ, followed by 10-1Z, 20-2Z, etc.

The CID Number appears on each page of the manuscript. The complete citation is used on the first page, and an abbreviated version on subsequent pages. Numbers in the index correspond to the last two digits of the six-digit CID Number. 


\title{
Contents
}

\author{
$\checkmark$ Authors \\ vii Conference Committee \\ ix Introduction
}

SESSION 1 REMOTE SENSING SYSTEM APPLICATIONS I

922304 Persistent observations of the Arctic from highly elliptical orbits using multispectral, wide field of view day-night imagers (Invited Paper) [9223-3]

922305 VIIRS reflective solar bands on-orbit calibration coefficient performance using imagery and moderate band intercomparisons [9223-4]

\section{SESSION 2 REMOTE SENSING SYSTEM APPLICATIONS II}

922307 Uncooled emissive infrared imagers for CubeSats (Invited Paper) [9223-6]

922308 Calibration of a system to collect visible-light polarization data for classification of geosynchronous satellites [9223-7]

\section{SESSION 3 ACTIVE REMOTE SENSING SYSTEMS}

$92230 \mathrm{~A}$ Control architecture for an adaptive electronically steerable flash lidar and associated instruments [9223-10]

\section{SESSION 4 INNOVATIONS IN REMOTE SENSING}

9223 OE Pattern recognition applied to infrared images for early alerts in fog [9223-14]

9223 OF Appreciation of the traffic effects on the RST by infrared thermography [9223-15]

$9223 \mathrm{OH}$ A hybrid algorithm for robust acoustic source localization in noisy and reverberant environments [9223-17]

POSTER SESSION

9223 0J An optical positioning sensor by combining optical projection and a virtual camera model [9223-18] 
Proc. of SPIE Vol. $9223922301-4$

Downloaded From: https://www.spiedigitallibrary.org/conference-proceedings-of-spie on 26 Apr 2023 Terms of Use: https://www.spiedigitallibrary.org/terms-of-use 


\section{Authors}

Numbers in the index correspond to the last two digits of the six-digit citation identifier (CID) article numbering system used in Proceedings of SPIE. The first four digits reflect the volume number. Base 36 numbering is employed for the last two digits and indicates the order of articles within the volume. Numbers start with 00, 01, 02, 03, 04, 05, 06, 07, 08, 09, 0A, 0B...0Z, followed by 10-1Z, 20-2Z, etc.

Boucher, Vincent, $\mathrm{OE}$

Buès, Michel, OF

Chun, Francis, 08

Cord, Aurélien, OE

Craner, Jeremy, OA

Davies, Angela, 0J

De Luccia, F., 05

Dessonville, Timothy, $\mathrm{OH}$

Dong, Yue, oJ

Dumoulin, Jean, $\mathrm{OE}$

Harris, Timothy, OA

Johnson, David, 04

Khalifa, Abderrahmen, OF

Marchetti, Mario, OE, OF

Masini, Paolo, 07

Matin, Mohammad, 08

Miller, Steven, 04

Morse, Edward, OJ

Moyer, D., 05

Mullany, Brigid, OJ

Puschell, Jeffery J., 04, 07

Rajagopalan, Ramesh, $\mathrm{OH}$

Rausch, K., 05

Ruppert, Lyle, OA

Speicher, Andy, 08

Tippets, Roger, 08

Vandermierden, N., 05

Zheng, Benrui, OJ 
Proc. of SPIE Vol. $9223922301-6$

Downloaded From: https://www.spiedigitallibrary.org/conference-proceedings-of-spie on 26 Apr 2023 Terms of Use: https://www.spiedigitallibrary.org/terms-of-use 


\section{Conference Committee}

Program Track Chair

Allen H.-L. Huang, University of Wisconsin-Madison (United States)

Conference Chairs

Philip E. Ardanuy, Raytheon Intelligence \& Information Systems (United States)

Jeffery J. Puschell, Raytheon Space \& Airborne Systems (United States)

Conference Program Committee

Robert M. Atlas, National Oceanic and Atmospheric Administration (United States)

Ni-Bin Chang, University of Central Florida (United States)

Stephen A. Cota, The Aerospace Corporation (United States)

Gerald J. Dittberner, Harris Corporation (United States)

William B. Gail, Microsoft Corporation (United States)

Xingfa Gu, Institute of Remote Sensing and Digital Earth (China)

M. Gregory Hammann, GeoEye, Inc. (United States)

Allen H.-L. Huang, University of Wisconsin-Madison (United States)

K. Dieter Klaes, European Organisation for the Exploitation of Meteorological Satellites (Germany)

Stephen A. Mango, NOAA / NESDIS Office of Satellite Operations (United States)

Jens Nieke, European Space Research and Technology Center (Netherlands)

Monesh Patel, Medtronic, Inc. (United States)

Carl F. Schueler, Schueler Consulting-Santa Barbara (United States)

Osman G. Sezer, Texas Instruments Inc. (United States)

Session Chairs

1 Remote Sensing System Applications I

Jeffery J. Puschell, Raytheon Space \& Airborne Systems (United States)

2 Remote Sensing System Applications II

Ni-Bin Chang, University of Central Florida (United States) 
3 Active Remote Sensing Systems

Philip E. Ardanuy, Raytheon Intelligence \& Information Systems (United States)

4 Innovations in Remote Sensing

Carl F. Schueler, Schueler Consulting-Santa Barbara (United States) 


\section{Introduction}

The fifth Remote Sensing System Engineering Conference was held on Monday, 18 August 2014, at the San Diego Convention Center as a part of the SPIE Optics + Photonics and Optical Engineering + Applications Annual Meeting. The goals of the Conference were, first and foremost, to exchange critical and invaluable lessons learned and best practices in the systems engineering of ground-, air-, and space-based remote sensing systems. Additional goals were to share existing and emerging design approaches, engineering methods, tools, and future trends for engineering remote sensing systems.

Chaired by Dr. Philip E. Ardanuy (Raytheon Intelligence \& Information Systems) and Dr. Jeffery J. Puschell (Raytheon Space \& Airborne Systems), the conference featured 21 diverse and interesting presentations on Remote Sensing System Applications, Active Remote Sensing Systems, and Innovations in Remote Sensing across four oral sessions, plus additional poster presentations in the evening session. The authors were international in breadth, with Asian and European engineers and scientists joining their American systems engineering colleagues for the conference. Topics discussed included: systems engineering best practices and lessons learned; system architecture and design; requirements, performance metrics, and measures of success; modeling and simulation tools and methods; design and integration of distributed architectures; use of commercial assets in future remote sensing systems; bridging and balancing across the science-toengineering and technologist-to-end-user valleys of "death and lost opportunities"; and the end user, effective data/information/system utilization, and optimum return on investment.

The conference chairs wish to thank the presenters and authors for their fascinating and innovative contributions, which spanned the full diversity of the field. The papers which follow include:

- Persistent observations of the Arctic from highly elliptical orbits using multispectral, wide field of view day-night imagers, by Jeffery Puschell of Raytheon Space \& Airborne Systems

- VIIRS reflective solar bands on-orbit calibration coefficient performance using imagery and moderate band intercomparisons, by D. Moyer of The Aerospace Corporation

- Uncooled emissive infrared imager for CubeSats, by Jeffery Puschell of Raytheon Space \& Airborne Systems

- Calibration of a system to collect visible-light polarization data for classification of geosynchronous satellites, by Andy Speicher of the University of Denver 
- Control architecture for an adaptive electronically steerable flash lidar and associated instruments, by Lyle Ruppert of Ball Aerospace \& Technologies Corporation

- Pattern recognition applied to infrared images for early alerts in fog, by Vincent Boucher of Cerema/DTer Ovest

- Appreciation of the traffic effects on the RST by infrared thermography, by Abderrahmen Khalifa of Cerema/DTer Est

- A hybrid algorithm for robust acoustic source localization in noisy and reverberant environments, by Ramesh Rajagopalan of the University of St. Thomas

- An optical positioning sensor by combining optical projection and a virtual camera model, by Benrui Zheng of The University of North Carolina at Charlotte

Philip E. Ardanuy Jeffery J. Puschell 